\title{
Diet and breeding habitat preferences of White-tailed Eagles in a northern inland environment
}

\author{
Camilla Ekblad $^{1}\left(\mathbb{D} \cdot\right.$ Hannu Tikkanen ${ }^{2} \cdot$ Seppo Sulkava $^{3} \cdot$ Toni Laaksonen $^{1} \oplus$
}

Received: 6 March 2020 / Revised: 15 October 2020 / Accepted: 3 November 2020 / Published online: 13 November 2020

(c) The Author(s) 2020

\begin{abstract}
Many apex predator populations are recolonizing old areas and dispersing to new ones, with potential consequences for their prey species and for livestock. An increasing population of the White-tailed Eagle (Haliaeetus albicilla) has settled north of the Arctic Circle in northern Finland, mainly at two big water reservoirs but also in areas with mainly terrestrial habitat. We examined nesting habitat preferences and prey use of White-tailed Eagles in this environment, where reindeer husbandry is a traditional livelihood and concerns are rising that the growing White-tailed Eagle population poses a threat to reindeer calves. Lakes, peat bogs, and marshlands were preferred habitats in the nesting territories. Fish constituted $64.3 \%$ of the identified prey items, with birds accounting for $28.5 \%$ and mammals $7.2 \%$. The nesting territory habitat within a $10 \mathrm{~km}$ radius and the latitude influenced the prey composition at both the group and species level. The occurrence of reindeer calves as prey increased with latitude but was not associated with any habitat. Knowledge of the diet and territory preferences can be used to predict future dispersal and local prey use of this species. Nesting White-tailed Eagles do not seem to pose a threat to traditional reindeer herding, but further research is needed regarding non-breeding sub-adults and whether the White-tailed Eagles actually kill reindeer calves or simply exploit their carcasses.
\end{abstract}

Keywords Bird of prey $\cdot$ Breeding territory $\cdot$ Human-wildlife conflict $\cdot$ Lapland $\cdot$ Raptor

\section{Introduction}

Apex predators play a key role in top-down regulation of ecosystems, often with cascading effects when an apex predator leaves or enters a system (Estes et al. 2011). In the past century, many apex predator populations crashed (Prugh et al. 2009; Estes et al. 2011), but some populations have recovered recently; for example large carnivores in Europe

Seppo Sulkava Deceased on 27 Jan 2019.

Electronic supplementary material The online version of this article (doi:https://doi.org/10.1007/s00300-020-02769-1) contains supplementary material, which is available to authorized users.

Camilla Ekblad

camilla.ekblad@utu.fi

1 Section of Ecology, Department of Biology, University of Turku, 20014 Turku, Finland

2 Ecology and Genetics Research Unit, University of Oulu, 90014 Oulu, Finland

3 Espoo, Finland and wolves (Canis lupus), sea otters (Enhydra lutris), and alligators (Alligator mississippiensis) in different parts of the USA (Chapron et al. 2014; Ripple et al. 2014; Silliman et al. 2018). Following the ban of organochloride pesticides and reduced persecution, the populations of apex raptors, such as Peregrine Falcons (Falco peregrinus) and Ospreys (Pandion Haliaeetus), have also recovered (Ratcliffe 2003; Poole 2019). The growing populations are spreading into new areas, often re-colonizing areas they once inhabited (Silliman et al. 2018). This return of apex predators is a complex issue. Even though their importance as regulators of food webs is commonly acknowledged, they cause conflicts with humans because they are considered competitors for prey resources or a threat to humans and/or livestock (Valkama et al. 2005; Prugh et al. 2009; Ripple et al. 2014; Nyhus 2016). The return of the predators may also conflict with the conservation of the prey species (Hipfner et al. 2012).

According to classical foraging theory, apex predators, as well as other foragers, should prefer the most profitable prey when it is abundant, and switch to less preferred prey when the abundance of the preferred prey declines below a certain threshold (Stephens and Krebs 1986). More recently, 
it has been noticed that predators also seek variation in their diets (Kohl et al. 2015). However, different predator individuals do not necessarily have equal opportunities for choosing prey. The abundance and availability of different prey species varies between habitats, thereby altering which prey is the most profitable (Ontiveros et al. 2005; Sih 2011) or available (Amar et al. 2004; Newsome et al. 2015). Territorial species therefore have to pay attention to prey availability when choosing a breeding territory. Species that select nesting site annually can choose different places in subsequent years if the environmental conditions or prey availability change (Arroyo et al. 2009; Vasko et al. 2011; Navarro-López et al. 2015). For species that generally choose a territory for life, the consequences of the selection are often lifelong and the associations between habitat and diet need further investigation.

Many raptor species are prime examples of territorial species that remain faithful to their breeding territory. They typically have relatively large territories that cover various types of habitats (Tapia and Zuberogoitia 2018). Some evidence supports habitat-driven intraspecific differences in the diet of raptors, as landscape characteristics can impact the diet of individual raptor pairs (Amar et al. 2004; Frey et al. 2011; Shin et al. 2013; Terraube et al. 2014; Bildstein 2017). Nevertheless, research has focused on species that specialize in a few prey species and habitats, whereas almost nothing is known about the connections between the use of multiple prey species and territory habitat characteristics.

The White-tailed Eagle (Haliaeetus albicilla) is a large raptor that typically lives and nests close to water. It was driven to the brink of extinction in the twentieth century in the area around the Baltic Sea due to persecution and to pollution by organochlorine pesticides, but after extensive conservation efforts the population started to grow in the 1980s (Stjernberg et al. 2005, 2016). In Finland, the core nesting areas are along the Baltic coast. As the population has grown, the White-tailed Eagles have expanded to new areas, as well as to areas where they historically have occurred but were missing for several decades (Högmander et al. 2020).

The reappearance of White-tailed Eagles in food webs from which they have been virtually absent in the recent past can have consequences for the prey species and cause management and conservation conflicts (Hipfner et al. 2012). In parts of the Baltic Sea, the Common Eider (Somateria mollissima) population has crashed in the outer archipelago since its peak in the 1990s (Below et al. 2019), probably in part due to growing White-tailed Eagle populations (Ekroos et al. 2012; Öst et al. 2018). This has created a conflict with eider hunting, as well as a concern for the survival of this prey species, which is classified as endangered in the Finnish red list (Hyvärinen et al. 2019). However, where the White-tailed Eagle has been re-introduced in Scotland and Ireland, financially more important conflicts with livestock herding have arisen with sheep herders (Simms et al. 2010; O'Rourke 2014). The original dissensus about the level of threat posed by the Whitetailed Eagles to the lambs, and the viability of the lambs eaten, has been met by the development of an action plan in Scotland (Scottish Natural Heritage 2017).

In the late 1960s, two big water reservoirs, Lokka (417 $\left.\mathrm{km}^{2}\right)$ and Porttipahta $\left(214 \mathrm{~km}^{2}\right)$, were constructed inland in northern Finland (Lapland). Historically, occasional White-tailed Eagle nestings were known in the area (Ollila et al. 2007), but the reservoirs provided novel breeding habitats that launched the expansion of the White-tailed Eagle population to the area. The first nesting event at Lokka was observed in 1977 (Sulkava et al. 1997), and by 2019, 86 nesting pairs were recorded in the reindeer herding area (WWF Finland, unpublished) (Fig. 1). The majority of the current territories in Lapland are located around these two water reservoirs, but today nests are present in other areas as well, with the second largest aggregation in the Kuusamo region in the southeastern part of the area (Fig. 2).

Molecular genetics has shown that the Lapland Whitetailed Eagle population has a northeastern origin and thus does not originate from the Baltic population (Ponnikas et al. 2013). The diet of the White-tailed Eagles nesting in Lapland was studied in the 1980s, when it consisted mostly of fish (69.2\%), followed by birds $(29.2 \%)$ and mammals (3.6\%). Reindeer calves (Rangifer tarandus tarandus) constituted $0.5 \%$ of the diet (by number of prey items; Sulkava et al. 1997). An update of the diet of White-tailed Eagles in the area is important, as the former study did not discriminate between habitats and the population has grown tenfold since, thereby enhancing the competition for territories and possibly inducing dispersal to sub-optimal habitats.

The growth of the White-tailed Eagle population in Lapland may awaken conflicts if the birds prey upon popular game species. So far, the main concern has been that they may kill reindeer calves, causing financial losses for reindeer herders. Herding of semi-domesticated reindeer is a traditional livelihood practiced in Lapland and plays important cultural and financial roles for the indigenous Sámi people in the northernmost municipalities (Kumpula et al. 2011), as well as for other inhabitants in the rest of the reindeer herding area (Jernsletten and Klokov 2002). The semi-domesticated reindeer graze freely in the spring- and summer pastures, also calving there. This makes them vulnerable to predators that are large enough to capture calves. In some parts of this area, around 10\% of the Golden Eagle (Aquila chrysaetos) diet, as measured by prey items, consists of reindeer calves (Sulkava et al. 1998; Johnsen et al. 2007). Concern has been raised that the growing population of White-tailed Eagles could also contribute to calf losses, as 


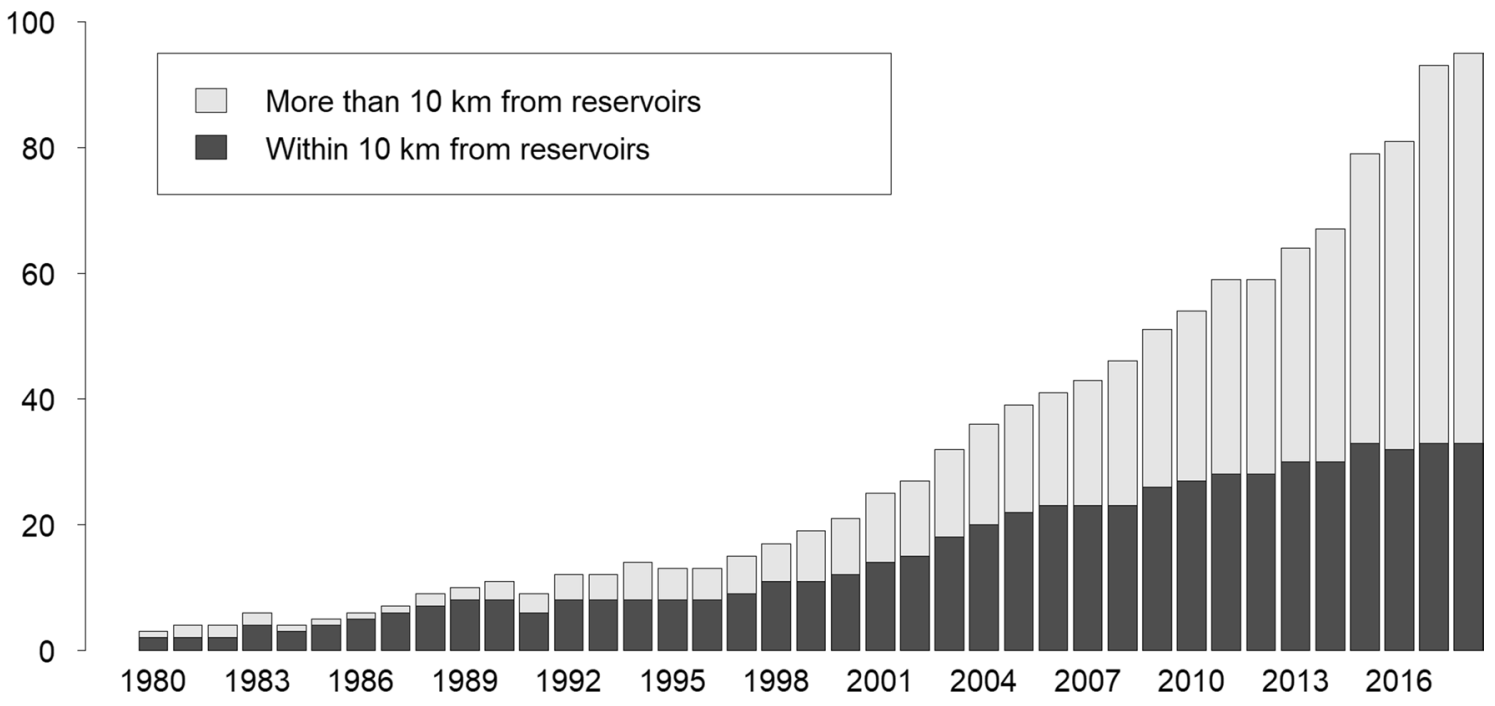

Fig. 1 The number of occupied White-tailed Eagle territories in the reindeer herding area each year since 1980. Territories within $10 \mathrm{~km}$ from the Lokka and Porttipahta reservoirs (dark bars) and farther than $10 \mathrm{~km}$ from them (light bars) are shown

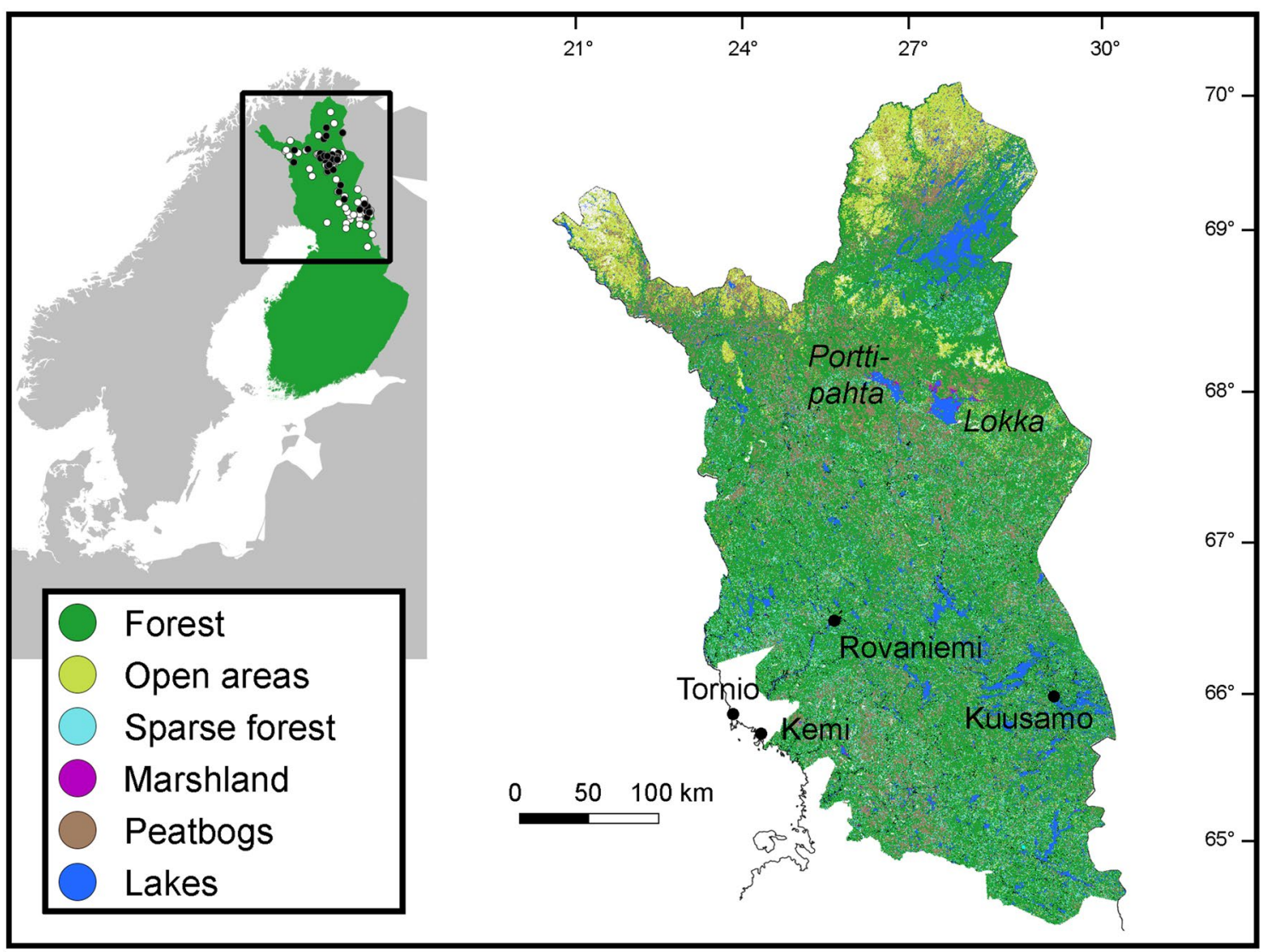

Fig. 2 The map shows the location of the reindeer herding area in Lapland in northern Finland. The habitat types in the area are shown in different colors. All known current and historical White-tailed Eagle territories in the area, as of 2018 , are plotted on the location map. Black dots indicate territories from which prey data are available, while white dots are territories with no available prey data. The densest aggregation is around the water reservoirs of Porttipahta and Lokka 
the White-tailed Eagle is about the same size as the Golden Eagle and has a partially overlapping diet.

Evaluation of the possible impacts of the growing Whitetailed Eagle population on their prey species requires an understanding of how the selection of territorial habitat by nesting eagles will affect the availability of prey species in each territory and, thereby, the eagle's diet. Only a few studies have addressed nesting habitat preferences for White-tailed Eagles. In Lithuania, a preference for various water bodies, as well as semi-open areas, was found within a calculated territory with a radius of $6 \mathrm{~km}$ (Treinys et al. 2016), whereas all White-tailed Eagle nests in Croatia are found within $1 \mathrm{~km}$ of some kind of water body (Radović and Mikuska 2009). Associations between the diet and the habitat in the nesting territory have, to our knowledge, been made only regarding the share of water and land (Helander 1983; Ekblad et al. 2016). A very recent paper from Lithuania examined the diet in different aquatic environments, but the terrestrial habitats were not further discriminated (Dementavičius et al. 2020). Nothing is known about these connections at high latitudes, such as in Lapland.

In the present study, we examined the diet and nesting habitat preferences of the recently expanded population of White-tailed Eagle in Finnish Lapland in an effort to understand the drivers behind the prey choice. A second goal was to evaluate to what extent the occurrence of reindeer calves in the diet of White-tailed Eagles is driven by these factors. Our aim is for this to be a first step toward understanding the possible impacts of this predator on its prey and the potential for conflicts in prey use between White-tailed Eagle and humans. Specifically, the aims of this study were (1) to investigate whether the White-tailed Eagles prefer certain habitats over others when choosing nesting territory; (2) to examine the diet of the nesting White-tailed Eagles and the connections between habitats in the territory and prey species in the diet; and (3) to identify possible factors that predict the occurrence of reindeer calves in the White-tailed Eagle diet.

\section{Material and methods}

\section{Study area}

Our study area is located mostly in Lapland, the northernmost region of Finland. The reindeer herding area, where reindeer are allowed to graze freely within the borders of 54 reindeer herding cooperatives, covers almost the same area. Exceptions are an area around the city of Kemi, which is excluded, and an extension in the south that belongs to the regions of North Ostrobothnia and Kainuu. Because we consider the reindeer aspect, our study takes place in the entire reindeer herding area, which, for simplicity, we refer to hereafter as Lapland. The study area is located north of latitude $64^{\circ} 28^{\prime} \mathrm{N}$ and has a size of $122936 \mathrm{~km}^{2}$, covering a third of Finland (Anon. 2015) (Fig. 2). The landscape is a mosaic of lakes, low forests, and peat bogs, with a growing proportion of tree-covered and open fells towards north. Human settlements are very scarce (mean 1.4 people $\mathrm{km}^{-2}$, Statistics Finland 2019). Fresh water covers $6.7 \%$ of the area (National Land Survey of Finland 2019). Conditions are harsh, with mean temperatures in April, when the Whitetailed Eagles start nesting, of $-1.5^{\circ} \mathrm{C}$ at the reservoirs and $-0.1{ }^{\circ} \mathrm{C}$ in the Kuusamo region $(2009-2018)$. At the reservoirs, the ground loses its snow cover, on average, on the 13th of May and in Kuusamo on the 9th of May (Official Statistics of Finland 2019).

\section{Study species and nest surveillance}

The White-tailed Eagle (H. albicilla) is a large bird of prey, with a wingspan of $195-245 \mathrm{~cm}$ and a weight of 4-7 kg. It lives and nests close to water (Ferguson-Lees and Christie 2001). Annually, almost all known nests are surveyed in Finland (Högmander et al. 2020). In Lapland, the monitoring has been coordinated and supported by Metsähallitus, a governmental organization. The nests are visited in May-June, when the breeding status of the pair is monitored. The number of nestlings is recorded, and if possible, the nestlings are measured and ringed by volunteers. In 2019, 86 occupied territories of White-tailed Eagles were detected in the reindeer herding area (WWF Finland, unpublished).

The reindeer ( $R$. tarandus tarandus) is a medium-sized ungulate. The calves, usually one per female, are born between May and June in the study area. They have a birthweight of 4-6 kg and their weight doubles in the first month (Anon. 2015). The maximum number of reindeer that can be left alive in the autumn, in total and in each cooperative, is set by the Ministry of Agriculture and Forestry of Finland (Reindeer Husbandry Act 848/1990). In 2017, the actual number of reindeer was 193 140. The number and density of reindeer increases with latitude. Data about the number of reindeers in different reindeer herding areas was obtained from the LIITERI database (Finnish Environment Institute 2019).

\section{Territorial size and habitat}

Breeding White-tailed Eagles show site fidelity; they have one or several nests in their territory and use them year after year (Cramp 1980). No unambiguous size for Whitetailed Eagle territories has been determined; therefore, we investigated the habitat around each known nest using three territory sizes based on information from other studies. In Germany, home ranges varied from 6-392 $\mathrm{km}^{2}$ (Krone and Treu 2018). This translates to a radius between 1.38 and 
$11.17 \mathrm{~km}$, if the territories were perfect circles. At the Baltic Sea coast, a radius of $2 \mathrm{~km}$ around the nests was used to describe habitat characteristics of the nesting landscape (Ekblad et al. 2016). In a study from Lithuania a radius of $6 \mathrm{~km}$ around the nests was used (Treinys et al. 2016). Unpublished data from two nesting White-tailed Eagles equipped with GPS-transmitters in Finland also reveal that $95 \%$ of all positions were within 11.8 and $13.2 \mathrm{~km}$ of their respective nests. The positionings were mainly from the coast or the vicinity of water bodies, while a large proportion of large water-free areas were not used. Thus, the territory sizes of White-tailed Eagles can vary widely depending on the environment.

The centers of the White-tailed Eagle territories were defined as their nests or, in cases with several nests, as the geometric average coordinates. We calculated the proportions of different landscape types (habitats) within buffers around the nests with $2 \mathrm{~km}, 5 \mathrm{~km}$, and $10 \mathrm{~km}$ radiuses. The landscape types were obtained from the open source CORINE 2012 Landcover data, with a resolution of $20 \mathrm{~m} \times 20 \mathrm{~m}$, produced by the Finnish Environment Institute (Härmä et al. 2013). The types considered were forests, open areas, forests with a canopy cover of $10-30 \%$ (hereafter sparse forest), marshlands (including overgrown lakes, reeds, flooded lands, and small water surfaces $>25 \mathrm{ha}$ ), peat bogs, and lakes. Additional information about the Corine landscape data is given in Online Resource 1. The calculations were performed with $\mathrm{R}$ version 3.5.0, and QGIS version 3.2.2. The calculations were made for every known Whitetailed Eagle territory in the reindeer herding area $(n=113)$.

\section{Diet data}

For this study, we have used all available data about Whitetailed Eagle diet in Lapland that can be assigned to a territory level. We identified prey remains from 763 different individuals; the remains were collected from nests at 83 different visits at 45 territories. The methods of data collection varied somewhat between years due to personnel turnover. The majority of the data was collected in 2017 and 2018 and was supplemented with information from 1993-2013. Additional data about sampled territories per year is provided in Online Resource 2.

In 2017, prey remains were collected from 15 active nests in July-August, both during the nest visits and after the breeding season. All prey remains found under the nests and, in some cases, in the nests were collected. In 2018, prey remains were collected from 14 nests, but only during the nest visits, in June-July. In total, we collected and identified prey items from 258 prey individuals in 2017 and 161 in 2018. In addition, the prey remains in four nests in 2017 and two in 2018 were photographed, which added a total of 10 items. In 2017, additional notes were made about 9 nests, stating the occurrence or non-occurrence and number of reindeer calves in each nest along with 17 other identified prey items, and documentation of the evidence for whether there was no, few, or many fish, birds and mammals. This was interpreted so, that 'few' was two and 'many' was five prey items, adding 46 items. After these additions, the total number of identified prey items from 2017-2018 was 463 .

The newly collected and the photographed prey items were identified to the highest possible level by SS with the help of reference material and guidebooks (März 1987). The number of items of each species was determined by the 'minimum method' (Oehme 1975). In this method, every prey remain from one species is considered to originate from the same individual, unless multiple remain parts are found that cannot originate from only one individual, such as beaks, lower jaws from one side (left or right), or feathers with differing distinct sex colors. The total number of individuals from a species is considered to be the number of the remains from maximum number of different individuals.

In 1993-2013, White-tailed Eagle ringer Seppo Ojala made notes about the prey in the nests during nests visits. Notes were made only for large and identifiable prey remains. Hence, notes are available only for some nests and from some years. The occurrence of reindeer calves, however, was always noted. In total, notes are available from 31 territories from 1993 to 2013, totaling 288 prey individuals.

The identified prey remains were pooled at the territory level for the analyses.

\section{Biases of prey data}

When collecting prey items, large and hard bones are better preserved than soft and small ones, which means that small fish and ducklings are underrepresented (Mersmann et al. 1992; Sulkava et al. 1997). The hard jaw bones of pike (Esox lucius) are found easily, so pike tend to be overrepresented (Sulkava et al. 1997). Bones of reindeer calves are also well preserved, and as all cases of reindeer calves were noted even if no other prey remains were collected, the proportion of reindeer calves is also overrepresented. Conversely, we use the number of prey items as units, which gives a somewhat different result than if biomass was used. We have no data regarding the density of the prey species in the territories; therefore, our data cannot be used to evaluate the choice of prey with regards to prey availability. No proportions based on weight estimates are given, as they are not essential for the analyses between diet and habitat.

These data consist both of systematically collected and identified prey items (2017-2018, 'new data', extended with some notes), as well as notes of easily identifiable remains (1993-2013, 'old data'). This means that the samples are not directly comparable in the two data sets. The old data set has a higher proportion of fish, whereas the new data contains 
more birds. In particular, the proportion of waterfowl (new data $17.8 \%$, old data $5.9 \%$ ) and of cyprinid fishes (new 3.2\%, old $15.3 \%$ ) showed considerable variation. As a precaution, we verified the analyses with different subsets of the data. The results regarding the connections between habitats and diet were highly consistent in the different subsets. The only differences were associated with the marshlands, which did not show any trend with only the new data. Regarding the occurrence of reindeer calves, a large proportion originated from the notes and did not show any trends if the data originating from the notes was discarded. Hence, we used all the data in the final analyses, as the results were almost identical, but the larger dataset gave better weight to the analyses and also detected a trend for the reindeer calves. Importantly, the sampling effort was the same, regardless of the surrounding landscape; hence, the bias in prey remain collection and identification in both the old and new data is similar in all habitats. Therefore, the results of the subsequent analyses can be considered robust despite the biases in the data.

\section{Statistical methods}

All statistical tests were performed with R, version 3.5.0 (R Core Team 2020). Prior to the actual analyses, we determined the best suited territory size for analyzing the diet composition in relation to the habitats. We concluded that it was a $10 \mathrm{~km}$ radius, so this size was used in all subsequent analyses. The analyses and results regarding the territory size are presented in Online Resource 3.

\section{Nesting habitat selection}

We examined whether some habitats were preferred by the White-tailed Eagles when choosing nesting territory. In addition to feeding grounds, the choice of nesting territory depends on different characteristics, such as disturbance factors and the availability of nesting trees. In this paper, we address only the feeding ground aspect. We used the dataset with all known current and past territories of White-tailed Eagles in Lapland ( $n=113)$. In QGIS, we assigned 226 random points $(=$ territories $\times 2)$ with a minimum distance of $4 \mathrm{~km}$ from each other in the research area and calculated the habitat proportions for a radius of $10 \mathrm{~km}$ in $\mathrm{R}$ in the same way as for the actual territories. We removed five random territories, that had more than $50 \%$ of their areas located outside the boundaries of the research area, leaving 221 random territories. The proportion of forests was removed from the analysis due to the high collinearity with the proportion of lake area, as indicated by the variance inflation factor (VIF) with threshold 3 (Zuur et al. 2010). A binomial generalized linear model (GLM) was used to test for differences between real and random territories, with real and random (1/0) territories as response variables and the proportion of different habitats as explanatory variables. If the proportion of some habitat differed significantly between the real and random territories, the White-tailed Eagles would show a preference for that habitat. The goodness of the predictors was tested by k-fold cross-validation (Picard and Cook 1984; Kohavi 1995) with the "cvAUC" package in R (LeDell et al. 2014). The data were divided randomly into five same-sized groups. Four of the groups were used to predict the habitat use in the last group. The confidence limits for the AUC-values were calculated by repeating all the analyses 100 times.

\section{Connections between diet and territory habitat}

The diet analyses were made at the territory level; all identified remains collected over the years from the same territory were pooled together to form the total number of prey for the particular territory. We used a binomial GLM to analyze the general diet composition of the major prey groups (fish, birds, and mammals), in different habitats within a $10 \mathrm{~km}$ radius from each nest. The number of target prey groups from each territory was used as the response variable, with the number of all prey items as the denominator. As explanatory variables we used the proportions of the different habitats (a value between 0 and 1 ). With proportional data, such as the habitats here, the variables inevitably may correlate with each other as they sum up to $100 \%$. We therefore used a VIF to test for correlation between the variables and a threshold of 3 for not including the variables in the same model (Zuur et al. 2010). The proportion of lakes and forest correlated and could not be used in the same model. As lakes are more suitable than forests as hunting grounds for Whitetailed Eagles, the proportion of forest was excluded from the analyses to avoid the correlation issue. Latitude was included in all models to test for geographical gradients. Consistently, latitude was also scaled to a value between 0 and 1 , as (latitude $-\min ($ latitude) $) / \delta$ (latitude), where min(latitude) is the southernmost latitude of the data and $\delta$ (latitude) is the range of latitudes in the data.

We also investigated the finer scale relationships between the occurrence of some species (or species groups) in the prey remains and nesting habitats. As with the major groups, we used a binomial $G L M$ with the number of target species from each territory as the response variable, and the number of all prey items as the denominator. As explanatory variables, we used only the habitats considered relevant for the target prey, along with latitude. Hence, lake and marshland were used as a proxy for predicting the availability of fish species; lake, peat bog and marshland were used for waterfowl and gulls (Larus spp.); peat bog and marshland for Common Cranes (Grus grus) and forest, sparse forest, and open areas for grouse (Tetraonidae spp).

To investigate all possible relationships between habitats and reindeer calves in the diet we also included, in addition 
to the habitats, the density of reindeer in each cooperative, calculated by the number of reindeer divided by the land area of the cooperative. Consistently, this value was scaled to a value between 0 and 1 .

\section{Results}

\section{Nesting habitat}

The main landscape types in the territories within a $10 \mathrm{~km}$ radius from the nest were forest, peat bogs, and lakes. Additionally, sparse forest, open areas, and marshes each constituted a mean percentage of 1.4-7.7 (Table 1). Other landscape types each constituted a mean of less than $0.6 \%$ and were excluded from the analyses.

The White-tailed Eagles clearly preferred some landscape types in the vicinity of their nests. The proportional area of lakes and peat bogs within a radius of $10 \mathrm{~km}$ (an area of 314 $\mathrm{km}^{2}$ ) from their nests was significantly higher than expected by random choice of territories (Table 1). The proportional area of marshlands was also higher in the real territories (Table 1 and Fig. 3). The accuracy of the predictors was high, as the distribution of 1/0-points was determined to be correct in $81 \%$ of the occasions (AUC $=0.81, \mathrm{Cl} 0.76 / 0.86$ ).

\section{Diet in general}

The prey brought to White-tailed Eagle nestlings in Lapland (identified as prey remains) consisted mostly of fish (64.3\%), birds $(28.5 \%)$, and, to a smaller extent, mammals $(7.2 \%)$ (Table 2). By far, the most common prey species was the pike E. lucius, which constituted half of all the prey items. Other important prey species or groups were waterfowl, grouse, and ides Leuciscus idus (Table 2). Reindeer calves constituted $3.1 \%$ of the prey items in these data (Table 2); however, as noted before, this number is an overestimate because the data in 1993-2013 and the notes from recent years included recordings of reindeer calves on occasions when no other species were recorded. Hence, the total proportion of mammals is also a slight overestimate, while the proportion of fish other than pike is likely underestimated, as the data have not been corrected for biases regarding prey remains detection.

\section{Diet in relation to habitat in the breeding territory}

For all the major prey groups, diet was associated with habitat. The proportion of fish increased with the proportions of lakes, marshlands, and peat bogs (Fig. 4a), and decreased with increasing proportions of sparse forest and with latitude (Table 3).

As fish and birds were the major prey groups, their proportions in the diet correlate with each other. The proportion of birds increased with the proportion of sparse forest and latitude and decreased with the increasing proportion of marshland (Table 3). The proportion of mammals decreased with an increasing proportion of marshland (Table 3 ).

The proportion of the most common prey remains, namely pike, increased with the increasing proportion of marshland and decreased with increasing latitude, while cyprinid fish increased with the increasing proportion of lakes (Fig. 4b) and marshlands, and burbot increased with lakes (Table 4).

Bird species (or groups of species) in the diet also varied with habitats. The proportion of waterfowl increased with latitude and decreased with the increasing proportion of peat bogs and marshlands (Table 4). Grouse increased with the increasing proportion of sparse forest (Fig. 4c) and Common Cranes increased with the increasing proportion of peat bogs
Table 1 Proportion (\%) of the major habitat types in the White-tailed Eagle territories with a radius of $10 \mathrm{~km}$ from the nest or the mean location of multiple nests and nesting territory habitat preferences of White-tailed Eagles obtained with a resource selection function $(R S F$, logistic regression) model comparing real territories with randomly assigned points

\begin{tabular}{|c|c|c|c|c|c|c|c|}
\hline \multirow[t]{3}{*}{ Landscape type } & \multirow{2}{*}{\multicolumn{3}{|c|}{$\frac{\text { Proportion in territory }}{\text { All territories }(n=113)}$}} & \multirow{3}{*}{$\begin{array}{l}\text { Territories with } \\
\text { prey data }(n=45) \\
\text { Mean }\end{array}$} & \multirow{2}{*}{\multicolumn{3}{|c|}{$\begin{array}{l}\text { Tot. } n \text { territories }=334 n \text { real }=113, n \\
\text { random points }=221\end{array}$}} \\
\hline & & & & & & & \\
\hline & Mean & Min & Max & & Estimate & $Z$ & $P$ \\
\hline (Intercept) & & & & & $-2.68 \pm 0.67$ & -4.00 & \\
\hline Forest & 50.05 & 4.38 & 77.61 & 44.69 & & & \\
\hline Lakes & 14.95 & 0.32 & 59.00 & 19.78 & $0.11 \pm 0.02$ & 5.13 & $<0.0001 * * *$ \\
\hline Peat bogs & 19.55 & 2.75 & 44.29 & 19.63 & $0.08 \pm 0.02$ & 4.51 & $<0.0001 * * *$ \\
\hline Marshlands & 1.37 & 0.00 & 6.82 & 4.02 & $0.32 \pm 0.14$ & 2.29 & $0.0222 *$ \\
\hline Open areas & 4.03 & 0.15 & 46.41 & 3.16 & $-0.04 \pm 0.02$ & -1.75 & 0.0795 \\
\hline Sparse forest & 7.73 & 0.05 & 16.52 & 6.94 & $0.05 \pm 0.04$ & -1.23 & 0.2196 \\
\hline Other & 2.31 & 0.06 & 9.73 & 2.14 & $0.07 \pm 0.07$ & 1.03 & 0.3052 \\
\hline
\end{tabular}

The estimate shows the coefficient for the changes in the probability of the presence of a nest (vs. a random spot) in the landscape in relation to the habitat variable. Significant $(p<0.05)$ results are shown in bold. The habitat proportions are shown separately for all territories $(n=113)$ and territories with prey data $(n=45)$. Sparse forest is forest with low $(10-30 \%)$ canopy cover 


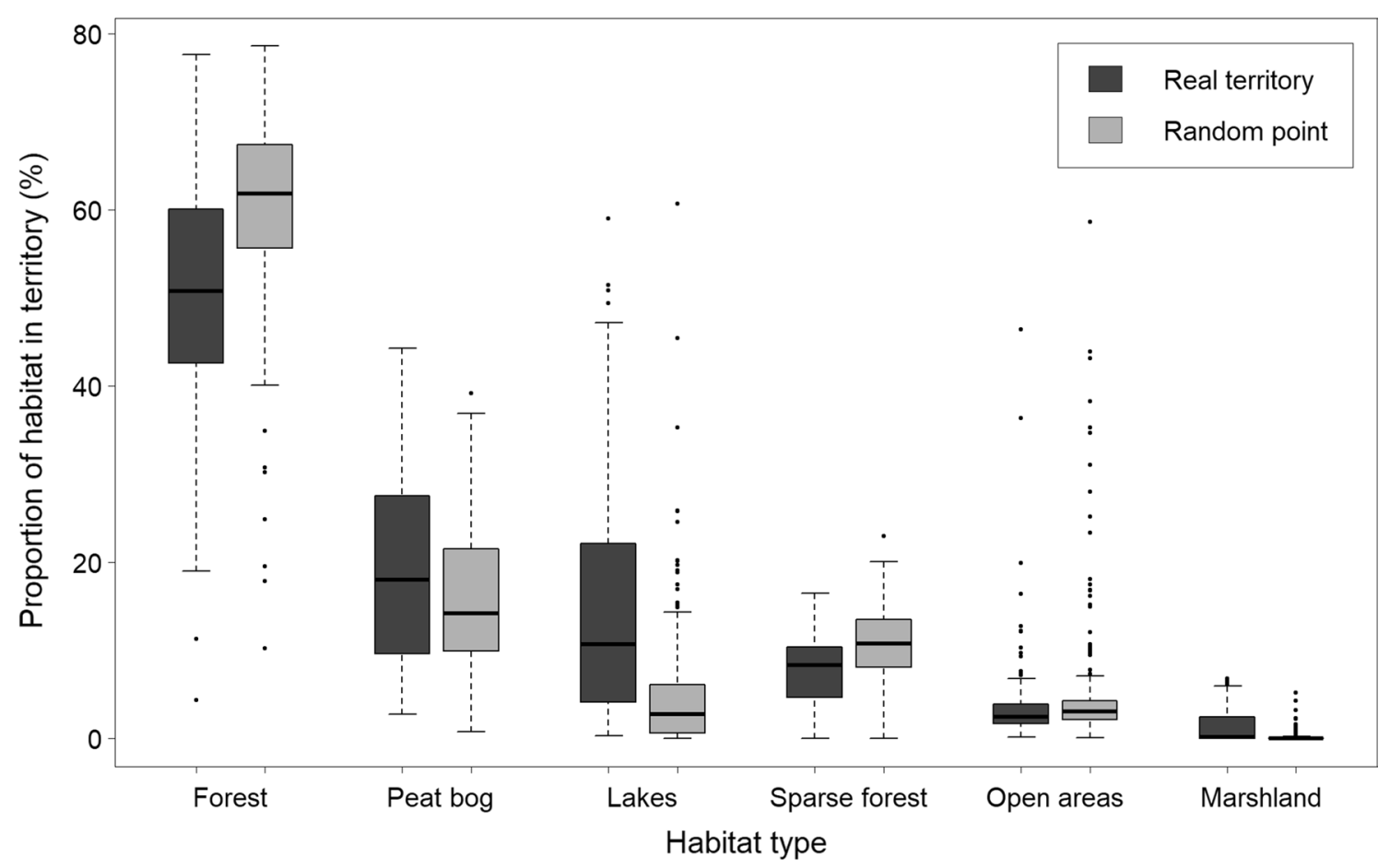

Fig. 3 Comparison between habitats in territories $(n=113)$ of White-tailed Eagles (within $10 \mathrm{~km}$ radius from the nest) and random points $(n=221)$ of same size in the same area. The White-tailed Eagles show a preference for lakes, peat bogs, and marshlands

(Fig. 4d, Table 4). The proportion of gulls in the diet was not associated with any habitat type (Table 4).

Reindeer calf remains solely increased with latitude. The habitat types in the territory and the density of reindeer in the cooperative did not correlate with reindeer calf remains. In 2017, remains of 9 reindeer calves were found at Whitetailed Eagle nests. In 2018, the remains of only one calf were found. Whether the calves were taken alive or as carcasses could not be determined.

\section{Discussion}

We showed that the diet of White-tailed Eagles nesting in Lapland is associated with the habitat in their nesting territory, and that some habitats, namely lakes, peat bogs, and marshlands, are strongly preferred in the nesting habitat. According to our results, the White-tailed Eagles prefer to nest in the vicinity of good fishing grounds. However, they also appear to be opportunistic and exploit common birds in terrestrial habitats. The use of reindeer calves and other mammals seems to be mainly occasional.

\section{Habitat preferences}

As the White-tailed eagles traditionally nest along the coast and are strongly associated with water, their preference for higher proportions of lakes in their territories was highly expected, and was also found to be the case in Lithuania (Treinys et al. 2016) and Croatia (Radović and Mikuska 2009). Although the proportion of lakes was the most significant habitat variable for nesting territories of the Whitetailed Eagles, they also showed a preference for peat bogs. Consistently, subadult White-tailed Eagles have been shown to prefer peat bogs as well at the Finnish coast (Tikkanen et al. 2018a). Peat bogs are probably good hunting grounds for White-tailed Eagles, as they fit their hunting techniques well. White-tailed Eagles are large raptors unable to hunt in closed forests. Their preferred hunting technique is to sit and perch over the landscape (Nadjafzadeh et al. 2016), making open peat bogs ideal. The proportion of marshland in Lapland is low compared to many other habitat types; nevertheless, the White-tailed Eagles showed a preference for them. In the area, marshlands often occur at shallow lake shores, which are good fishing grounds. The preference for marshlands might also be a proxy for shallow lake shores. In contrast to the birds in Lithuania (Treinys et al. 2016), the White-tailed Eagles in Lapland did not show a preference for open areas or sparse forests, even though those could also potentially fit their hunting techniques.

Estimating the available foraging habitat types within a certain radius of the nest is somewhat problematic as the White-tailed Eagles are known to use only some of the area for foraging, and they can exploit distant fishing grounds 
Table 2 Main prey groups and species of white-tailed eagles nesting in Lapland, in terms of numbers of prey individuals and the percentage of all prey items identified (in groups containing $>1 \%$ of items)

\begin{tabular}{|c|c|c|}
\hline & $\mathrm{n}$ & $\%$ \\
\hline Fish & 490 & 64.2 \\
\hline Pike (Esox lucius) & 380 & 49.8 \\
\hline Ide (Leuciscus idus) & 42 & 5.5 \\
\hline Other Cyprinid fish spp. (Cyprinidae) & 9 & 1.2 \\
\hline Burbot (Lota lota) & 21 & 2.8 \\
\hline Perch (Perca fluviatilis) & 9 & 1.2 \\
\hline Other or undefined fish & 29 & 3.8 \\
\hline Birds & 218 & 28.6 \\
\hline Waterfowl & 88 & 12.6 \\
\hline - Mallard (Anas platyrhynchos) & 21 & 2.8 \\
\hline - Common Teal (Anas crecca) & 12 & 1.6 \\
\hline - Goldeneye (Bucephala clangula) & 12 & 1.6 \\
\hline - Mergansers (Mergus \& Mergellus spp.) & 21 & 2.8 \\
\hline Grouse & 45 & 5.9 \\
\hline - Capercaillie (Tetrao urogallus) & 19 & 2.5 \\
\hline - Willow Ptarmigan (Lagopus lagopus) & 10 & 1.3 \\
\hline - Black Grouse (Lyrurus tetrix) & 10 & 1.3 \\
\hline Common Crane (Grus grus) & 18 & 2.4 \\
\hline Waders (Scolopacidae) & 9 & 1.2 \\
\hline Gulls (Larus spp.) & 16 & 2.1 \\
\hline Other or undefined birds & 51 & 6.7 \\
\hline - Geese (Anser / Branta spp.) & 8 & 1.1 \\
\hline - Corvids (Corvidae) & 16 & 2.1 \\
\hline Mammals & 55 & 7.2 \\
\hline Reindeer calves & 24 & 3.1 \\
\hline Other mammals & 31 & 4.1 \\
\hline - Hares (Lepus sp.) & 14 & 1.8 \\
\hline - Adult reindeer (Rangifer tarandus) & 8 & 1.1 \\
\hline Tot & 763 & 100 \\
\hline
\end{tabular}

located up to $12-14 \mathrm{~km}$ away from their nest. A perfect model would take into account only the areas actually used by the individual White-tailed Eagles, but determining these areas would require satellite transmitters or extensive fieldwork to follow each individual pair, which is not possible to execute on a large scale. Forest is the main landscape type in the area, and White-tailed Eagles require robust trees for their nests, but they did not explicitly select forest in their nesting territory as hunting ground. The unused areas consist mainly of forest; hence, the proportions of preferred hunting habitats should be a good proxy for the areas actually used by the White-tailed Eagles. We showed that the White-tailed Eagles prefer some habitats in their nesting territories associated with foraging, and we linked these habitats to different use of prey species. In addition, White-tailed Eagles nesting in territories with larger proportions of a non-preferred habitat were able to utilize it, as shown by the prey composition.
The landscape composition of a theoretical circular territory with radius $10 \mathrm{~km}$ can therefore be used to predict the diet composition of White-tailed Eagle pairs in northern Finland.

\section{Diet in general}

Fish, especially pike, form the core of the diet of Whitetailed Eagles nesting in Lapland. As expected, the proportion of fish increased with proportion of lake and marshland in the nesting habitat. For burbot (Lota lota), the increase was just associated with lakes, but for cyprinid fish and pike, marshland also caused an increase. For pike, the increase was larger for marshlands than for lakes. Pike spawn in the spring, just after the ice melting, in shallow waters such as flooded marshlands (Casselman and Lewis 1996), where they are easy prey for White-tailed Eagles. Outside the spawning season, mature pike also often occur in shallow, vegetation-rich areas (Casselman and Lewis 1996). The marshland habitat is mainly found at the shores of lakes, indicating shallow waters suitable for fishing. These factors could explain why the proportion of fish and pike in the diet of a pair is better explained by the proportion of marshland than by the lake area in the territory.

Bird species occur in much more diverse habitats (in the available GIS data) than fish do, which complicates the investigation of their occurrence as a group. The most significant association with habitat for birds as a group was that their occurrence in the diet increased with sparse forest. This relationship was clearly driven by grouse that inhabit this kind of forests and are the most available bird prey in the size-span suitable for White-tailed Eagles in the habitat (Väisänen et al. 2011).

Waterfowl and gulls are typically associated with marshlands and lakes, but their proportion as remains did not increase in territories with higher proportions of these habitats. Instead, their proportion decreased with marshland. The White-tailed Eagle pairs that ate waterfowl and gulls were often nesting close to lakes or rivers, but remains of these species were also completely missing from the nests of many pairs nesting close to water. This negative relationship may mirror the high occurrence of pike in this habitat. White-tailed Eagles nesting close to water may principally choose fish in these habitats and use waterfowl and gulls opportunistically when encountered. Fish are shown to be the preferred prey of White-tailed Eagles in inland landscapes of Germany (Nadjafzadeh et al. 2013), in agreement with the findings in the present study, and this seems to hold true as well in northern inland landscapes. The same study showed that mammals were the least preferred prey (Nadjafzadeh et al. 2013), which also seems to be the case in Lapland. First, their share of the total prey is small. Second, no habitats where mammals mainly occur were preferred by the White-tailed Eagles. Third, the only habitat types 

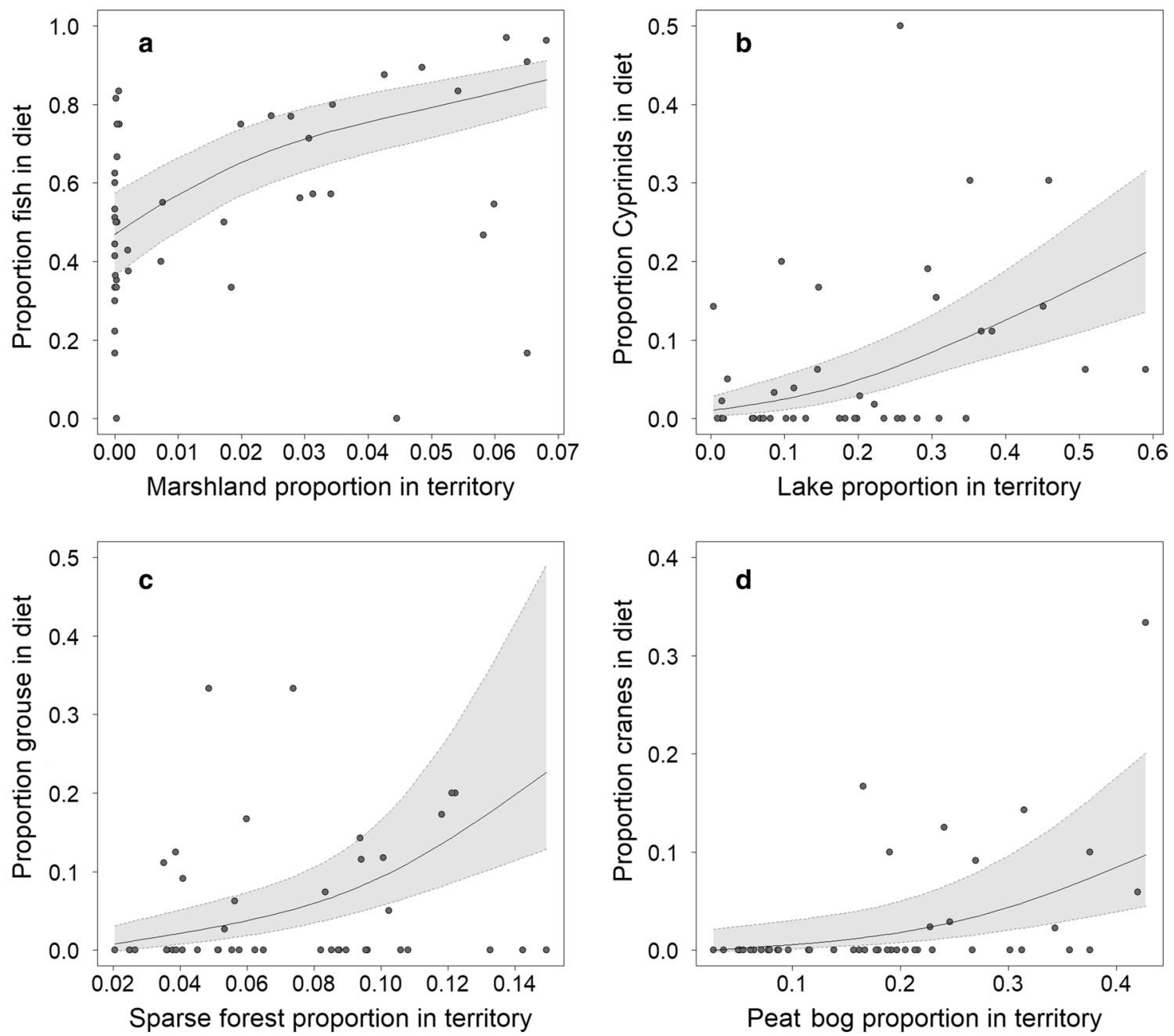

Fig. 4 Relationships between proportion of habitat around the nest at a $10 \mathrm{~km}$ radius and prey items in the diet of White-tailed Eagles in Lapland. The $\mathrm{x}$-axis shows the proportion of the particular habitat type in the territory, and the y-axis shows the proportion of prey in

the identified prey material. Only significant relationships are shown (see Table 4). The dots are actual means (over all the years, if many) for each territory, while the lines are model-based estimates with confidence intervals (grey shade)

Table 3 Estimates of the occurrence of major prey groups of White-tailed Eagles depending on proportions of different habitats around their nests within a radius of $10 \mathrm{~km}$ as obtained from a generalized linear model (GLM)

\begin{tabular}{|c|c|c|c|c|c|c|c|c|c|}
\hline \multirow[t]{2}{*}{ Habitat } & \multicolumn{3}{|l|}{ Fish $(n=490)$} & \multicolumn{3}{|l|}{ Birds $(n=218)$} & \multicolumn{3}{|c|}{ Mammals $(n=55)$} \\
\hline & Estimate & $z$ & $P$ & Estimate & $z$ & $p$ & Estimate & $z$ & $P$ \\
\hline (Intercept) & $1.01 \pm 0.50$ & 2.05 & $0.0406^{*}$ & $-1.81 \pm 0.53$ & -3.43 & $0.0006 * * *$ & $-1.63 \pm 0.86$ & -1.90 & 0.0581 \\
\hline Latitude & $-2.12 \pm 0.46$ & -4.62 & $<0.0001 * * *$ & $1.85 \pm 0.46$ & 4.00 & $<0.0001 * * *$ & $0.84 \pm 0.70$ & 1.21 & 0.2282 \\
\hline Marshland & $18.7 \pm 4.97$ & 3.77 & $0.0002 * * *$ & $-12.3 \pm 5.30$ & -2.33 & 0.0199* & $-22.6 \pm 9.23$ & -2.45 & $0.0143 *$ \\
\hline Sparse forest & $-8.49 \pm 3.83$ & -2.21 & $0.0268 *$ & $11.8 \pm 4.02$ & 2.93 & $0.0034 * *$ & $-4.85 \pm 6.33$ & -0.77 & 0.4442 \\
\hline Lake & $1.99 \pm 0.75$ & 2.65 & $0.0081 * *$ & $-1.15 \pm 0.79$ & -1.46 & 0.1455 & $-2.77 \pm 1.55$ & -1.79 & 0.0737 \\
\hline Peat bog & $2.42 \pm 1.13$ & 2.14 & $0.0322 *$ & $-1.88 \pm 1.11$ & -1.69 & 0.0909 & $-1.31 \pm 1.61$ & -0.82 & 0.4151 \\
\hline Open areas & $4.26 \pm 4.79$ & 0.89 & 0.3733 & $-6.36 \pm 5.21$ & -1.22 & 0.2217 & $3.58 \pm 6.43$ & 0.56 & 0.5777 \\
\hline
\end{tabular}

Significant $(p<0.05)$ and indicative $(p<0.1)$ results are shown in bold. Sparse forest stands for transitional forests with low canopy cover $(10-$ $30 \%$ ) 
Table 4 Occurrence of prey types in the prey of White-tailed Eagles in relation to their nesting territory habitats within a radius of $10 \mathrm{~km}$ from the nest

\begin{tabular}{|c|c|c|c|c|c|c|c|c|c|c|c|c|}
\hline \multirow{2}{*}{$\begin{array}{l}\text { Proportion habi- } \\
\text { tat in territory }\end{array}$} & \multicolumn{3}{|c|}{ Pike Esox lucius $(n=380)$} & \multicolumn{5}{|c|}{ Cyprinid fish $(n=51)$} & \multicolumn{4}{|c|}{ Burbot Lota lota $(n=21)$} \\
\hline & Estimate & $\mathrm{Z}$ & $\mathrm{p}$ & Estimate & \multicolumn{2}{|l|}{$\mathrm{Z}$} & \multicolumn{2}{|l|}{$\mathrm{P}$} & \multicolumn{2}{|c|}{ Estimate } & $\mathrm{Z}$ & $\mathrm{P}$ \\
\hline (Intercept) & $0.59 \pm 0.21$ & 2.77 & $0.0057 * *$ & $-4.28 \pm 0.62$ & \multicolumn{2}{|c|}{-6.85} & \multicolumn{2}{|c|}{$<0.0001 * * *$} & \multicolumn{2}{|c|}{$-7.31 \pm 1.93$} & -3.79 & $0.0002 * * *$ \\
\hline Lake & $0.14 \pm 0.55$ & 0.26 & 0.7990 & $3.74 \pm 0.99$ & \multicolumn{2}{|c|}{3.77} & \multicolumn{2}{|c|}{$0.0002 * * *$} & \multicolumn{2}{|c|}{$4.73 \pm 1.52$} & 3.11 & $0.0019 * *$ \\
\hline Marshland & $18.0 \pm 3.73$ & 4.82 & $<0.0001 * * *$ & $19.1 \pm 7.23$ & \multicolumn{2}{|c|}{2.64} & \multicolumn{2}{|c|}{$0.0084 * *$} & \multicolumn{2}{|c|}{$14.8 \pm 10.5$} & 1.41 & 0.1586 \\
\hline Latitude & $-1.87 \pm 0.35$ & -5.38 & $<0.0001 * * *$ & $0.03 \pm 0.99$ & 0.0 & & 0.9751 & & $2.93 \pm 2$ & & 1.15 & 0.2504 \\
\hline Proportion & Waterfowl $(n=$ & 87) & & Gulls Larus sp & $(n=16)$ & & & Com & mon Cran & e Grus $g$ & grus $(n=$ & \\
\hline ritory & Estimate & $\mathrm{Z}$ & $\mathrm{P}$ & Estimate & $\mathrm{Z}$ & $\mathrm{P}$ & & Estin & nate & $\mathrm{Z}$ & $\mathrm{p}$ & \\
\hline (Intercept) & $-1.79 \pm 0.39$ & -4.60 & $<0.0001 * * *$ & $-4.27 \pm 0.97$ & -4.39 & $<0$ & $0001 * * *$ & -5. & $9 \pm 1.31$ & -4.56 & $<0.00$ & $1 * * *$ \\
\hline Lake & $0.05 \pm 1.01$ & 0.05 & 0.9581 & $1.68 \pm 2.01$ & 0.84 & 0.40 & & & & & & \\
\hline Peat bog & $-3.87 \pm 1.27$ & -3.04 & $\mathbf{0 . 0 0 2 4} * *$ & $-1.68 \pm 3.73$ & -0.45 & 0.65 & & 9.93 & \pm 3.45 & 2.88 & 0.0040 & \\
\hline Marshland & $-25.1 \pm 7.19$ & -3.50 & $0.0005 * * *$ & $4.78 \pm 12.6$ & 0.38 & 0.70 & & 7.71 & \pm 13.2 & 0.59 & 0.5585 & \\
\hline Latitude & $1.60 \pm 0.46$ & 3.51 & $0.0005 * * *$ & $0.32 \pm 1.31$ & 0.25 & 0.80 & & -0.4 & $7 \pm 2.25$ & -0.21 & 0.8330 & \\
\hline Proportion habita & Grous & e $(n=45$ & & & & & Reinde & eer cal & ves $(n=2$ & & & \\
\hline t人iniviy & Estim & & $\mathrm{Z}$ & $\mathrm{p}$ & & & Estima & & & $\mathrm{Z}$ & & $\mathrm{p}$ \\
\hline (Intercept) & -4.9 & $2 \pm 1.22$ & -4.03 & $<0$ & $.0001 * * *$ & & -4.4 & $4 \pm 1.8$ & & -2.4 & & $0.0139 *$ \\
\hline Forest & -0.4 & $6 \pm 1.57$ & -0.29 & & .771 & & & & & & & \\
\hline Sparse forest & 26.2 & \pm 6.15 & 4.25 & $<0$ & $.0001 * * *$ & & -7.5 & $7 \pm 10$ & & -0.7 & & 0.4854 \\
\hline Open areas & 5.4 & $5 \pm 9.73$ & 0.56 & & .575 & & 5.3 & $9 \pm 7$ & & 0.75 & & 0.4519 \\
\hline Lake & & & & & & & -1.2 & $1 \pm 2$ & & -0.5 & & 0.5896 \\
\hline Peat bog & & & & & & & 1.2 & $1 \pm 2$ & & 0.50 & & 0.6191 \\
\hline Marshland & & & & & & & -22.2 & $29 \pm 1$ & & -1.7 & & 0.0890 \\
\hline Latitude & 0.1 & $4 \pm 0.80$ & 0.17 & & .862 & & & $0 \pm 1$ & & 2.23 & & $0.0260 *$ \\
\hline Reindeer density & & & & & & & -1.4 & $3 \pm 1$ & & -0.9 & & 0.3361 \\
\hline
\end{tabular}

All models are in the form [Proportion of target species] intercept + habitat_x + habitat_y $+\ldots+$ habitat $n+$ latitude. For the choice of potential explanatory habitat variables for each prey group, see methods

Significant $(p<0.05)$ and indicative $(p<0.1)$ results are shown in bold. $n$ is the number of identified prey items of each species or group. $d f$ for all species $=44$

that were associated with mammals, namely marshlands and lakes, showed negative correlations. The White-tailed Eagles did not choose mammals in any habitat and avoided them in environments where fish were abundant.

The general prey composition in this study was very similar to the previous one described in the 1980s (Sulkava et al. 1997), indicating that no major turnovers have happened regarding the prey availability. The Common Crane, however, occurred to a greater extent in this study $(2.4 \%$ of the prey) than in the previous one $(0.4 \%)$. Crane occurrence grew with peat bog, which also was a preferred habitat. It is possible that the population is about to be saturated around the reservoirs, and new pairs are now occupying alternative habitats with more peat bogs. Grouse were also slightly more abundant in this study (5.9\% vs. $3.7 \%)$, which could indicate that more pairs inhabit areas with sparse forest. This habitat is suitable as a hunting ground for White-tailed Eagles, albeit not preferred in this area.

\section{Reindeer calves in the diet}

The reindeer calf remains were not associated with any habitat type, nor with reindeer density in a cooperative. However, their appearance in the diet increased with latitude. The number and density of free ranging reindeer also grows towards north (Finnish Environment Institute 2019), where the forests are sparser and the trees grow shorter. Reindeer calves should hence be easier to access in the north, both by availability and approachability. 
In 2017, considerably more reindeer calf remains were found at the White-tailed Eagle nests than were found in 2018. The snow cover in the winter of 2017-2018 around the water reservoirs was thicker than in the winter 2016-2017, but spring and the snow melt were earlier in 2018 (Official Statistics of Finland 2019). In Norway, deep snow in the spring negatively affects the survival of reindeer calves (Tveraa et al. 2003) and the reproductive rates are lower for reindeer in springs when the snow melt is late (Helle and Kojola 2008). A majority of the calf mortality occurs at birth or within a week thereafter (Miller and Barry 2009). The higher occurrence of reindeer calves in nests in 2017 may be explained by a weaker condition and higher mortality of the calves due to the late spring snow melt. This research concerns only the connections between territory habitats and prey use by nesting White-tailed Eagles and does not allow for answering other important questions regarding the matter. Our findings, however, indicate that the nesting White-tailed Eagles do not seek out reindeer calves in any habitat; rather, the eagles exploit the calves when the calves are available. Scavenging birds are commonly mistakenly assumed by herders to have killed their prey (Duriez et al. 2019), even though they are just utilizing available resources. We currently do not know whether White-tailed Eagle have killed the reindeer calves or are scavenging them. However, successful co-existence between these predators and livestock herders crucially requires the involvement of the herders, along with conservation biologists, in the management, as well as consideration of the socio-economic aspects of that co-existence (Bennett 2016; O’Rourke 2014).

\section{Conclusions and implications}

To conclude, our research highlights preferences of nesting habitat of White-tailed Eagles in an inland environment and how these preferences are associated with the nestling diet. The remains of prey species mostly reflect the habitat preferences of the prey, while the preferred territory habitats in turn reflects the occurrence of the preferred prey.

Comprehensive monitoring of raptor populations, where the individuals use large areas in vast, inaccessible landscapes, is difficult, expensive, time-consuming, and often simply impossible. Our results can be used to predict the prey use of White-tailed Eagles at the landscape-level and potentially also the future dispersion of a growing population in Lapland. Additional research is needed to refine predictors beyond habitats and feeding grounds using models that take into account additional factors, such as the availability of nesting trees, the distance to other White-tailed Eagle nests, and human disturbance (Tikkanen et al. 2018b).

Reindeer calves are included in the diet of White-tailed Eagle nestlings in small proportions, with a slightly larger proportion in the northern areas. The numbers of reindeer calves eaten, but not necessary killed, by the nesting Whitetailed Eagles are so small that at least the nesting whitetailed eagles do not appear to pose a threat to reindeer herding. More research is needed, however, to estimate the total loss of calves due to predation by White-tailed Eagles in the area, including the predation by sub-adult White-tailed Eagles and the viability of the calves that are eaten.

Acknowledgements This article is dedicated to our devoted colleague professor emeritus Seppo Sulkava, who passed away in January 2019, while identifying prey remains of White-tailed Eagles at his home at the age of 87 years. We thank Fabio Balotari-Chiebao for help with the spatial data extracting procedure and Heikki Lokki and Torsten Stjernberg, who have maintained the White-tailed Eagle database for WWF Finland. Great thanks go to Olli-Pekka Karlin along with Lea Maalismaa, Jarmo Ahtinen, and Jouni Lamminmäki, for conducting the field work and Seppo Ojala for providing additional old prey data and Kai Leppimäki and Markku Saarinen for additional new prey data. We also thank Jouko Kumpula and two anonymous reviewers for their valuable comments on the manuscript. Tuomo Ollila from Metsähallitus coordinates the nest monitoring in Lapland. Prof. Pertti Saurola has maintained the satellite tracking data that were used to estimate maximum distances moved during the breeding season. The fieldwork was conducted with funding from the Ministry of Environment (project to TL), and funding for the research and writing was obtained from Svenska Kulturfonden and Societas pro Fauna et Flora Fennica (to CE).

Funding Open access funding provided by University of Turku (UTU).

Open Access This article is licensed under a Creative Commons Attribution 4.0 International License, which permits use, sharing, adaptation, distribution and reproduction in any medium or format, as long as you give appropriate credit to the original author(s) and the source, provide a link to the Creative Commons licence, and indicate if changes were made. The images or other third party material in this article are included in the article's Creative Commons licence, unless indicated otherwise in a credit line to the material. If material is not included in the article's Creative Commons licence and your intended use is not permitted by statutory regulation or exceeds the permitted use, you will need to obtain permission directly from the copyright holder. To view a copy of this licence, visit http://creativecommons.org/licenses/by/4.0/.

\section{References}

Amar A, Arroyo B, Redpath S, Thirgood S (2004) Habitat predicts losses of red grouse to individual hen harriers. J Appl Ecol 41:305-314. https://doi.org/10.1111/j.0021-8901.2004.00890.x

Anon. (2015) Reindeer - Poro. The Reindeer Herders' Association. https://paliskunnat.fi/reindeer/wp-content/uploads/2015/10/reind eer_english_web.pdf. Accessed 8.2. 2019

Arroyo B, Amar A, Leckie F, Buchanan GM, Wilson JD, Redpath S (2009) Hunting habitat selection by hen harriers on moorland: Implications for conservation management. Biol Conserv 142:586-596. https://doi.org/10.1016/j.biocon.2008.11.013

Below A, Lehikoinen A, Mikkola-Roos M, Kurvinen L, Laaksonen T (2019) Saaristolintukantojen kehitys vuosina 1980-2018. Linnutvuosikirja 2018:56-57 ([in Finnish with English summary])

Bennett NJ (2016) Using perceptions as evidence to improve conservation and environmental management. Conserv Biol 30:582-592. https://doi.org/10.1111/cobi.12681 
Bildstein KL (2017) Raptors: The Curious Nature of Diurnal Birds of Prey. Cornell University Press, Ithaca, NY

Burnham KP, Anderson DR (2002) Model Selection and Multimodel Inference: A Practical Information-Theoretic Approach. SpringerVerlag, New York

Casselman J, Lewis C (1996) Habitat requirements of northern pike (Esox lucius). Can J Fish Aquat Sci 53:161-174

Chapron G, Kaczensky P, Linnell JDC, Von Arx M, Huber D, Andrén H, López-Bao JV, Adamec M, Álvares F, Anders O, Balčiauskas L, Balys V, Bedő P, Bego F, Blanco JC, Breitenmoser U, Brøseth H, Bufka L, Bunikyte R, Ciucci P, Dutsov A, Engleder T, Fuxjäger C, Groff C, Holmala K, Hoxha B, Iliopoulos Y, Ionescu O, Jeremić J, Jerina K, Kluth G, Knauer F, Kojola I, Kos I, Krofel M, Kubala J, Kunovac S, Kusak J, Kutal M, Liberg O, Majić A, Männil P, Manz R, Marboutin E, Marucco F, Melovski D, Mersini K, Mertzanis Y, Mysłajek R (2014) Recovery of large carnivores in Europe's modern human-dominated landscapes. Science 346:1517-1519. https://doi.org/10.1126/science.1257553

Cramp S (1980) Handbook of the birds of Europe, the Middle East and North Africa: the birds of the Western Palearctic, vol 2. Oxford University Press, Oxford, Hawks to bustards

Dementavičius D, Rumbutis S, Virbickas T, Vaitkuvienė D, Dagys M, Treinys R (2020) Spatial and temporal variations in the White-tailed Eagle Haliaeetus albicilla breeding diet revealed by prey remains 67:206-216. https://doi.org/10.1080/00063 657.2020 .1808591

Duriez O, Descaves S, Gallais R, Neouze R, Fluhr J, Decante F (2019) Vultures attacking livestock: a problem of vulture behavioural change or farmers' perception? Bird Conserv Int 29:437-453. https://doi.org/10.1017/S0959270918000345

Ekblad C, Sulkava S, Stjernberg T, Laaksonen T (2016) Landscapescale gradients and temporal changes in the prey species of the white-tailed eagle (Haliaeetus albicilla). Ann Zool Fenn 53:228 240. https://doi.org/10.5735/086.053.0401

Ekroos J, Öst M, Karell P, Jaatinen K, Kilpi M (2012) Philopatric predisposition to predation-induced ecological traps: habitatdependent mortality of breeding eiders. Oecologia 170:979-986. https://doi.org/10.1007/s00442-012-2378-9

Estes JA, Terborgh J, Brashares JS, Power ME, Berger J, Bond WJ, Carpenter SR, Essington TE, Holt RD, Jackson JBC, Marquis RJ, Oksanen L, Oksanen T, Paine RT, Pikitch EK, Ripple WJ, Sandin SA, Scheffer M, Schoener TW, Shurin JB, Sinclair ARE, Soulé ME, Virtanen R, Wardle DA (2011) Trophic downgrading of planet Earth. Science 333:301-306. https://doi.org/10.1126/ science. 1205106

Ferguson-Lees J, Christie D (2001) Raptors of the world. Christopher Helm Publishers, London

Finnish Environment Institute (2019) Habitat Information Service LIITERI. https://liiteri.ymparisto.fi/. Accessed 8.2. 2019

Frey C, Sonnay C, Dreiss A, Roulin A (2011) Habitat, breeding performance, diet and individual age in Swiss Barn Owls (Tyto alba). J Ornithol 152:279-290

Helander B (1983) Food ecology of the white-tailed sea eagle Haliaeetus albicilla in Sweden. - In: Reproduction of the whitetailed sea eagle Haliaeetus albicilla (L.) in Sweden, in relation to food and residue levels of organochlorine and mercury compounds in the eggs. Dissertation, University of Stockholm

Helle T, Kojola I (2008) Demographics in an alpine reindeer herd: effects of density and winter weather 31:221-230. https://doi. org/10.1111/j.0906-7590.2008.4912.x

Hipfner MJ, Blight LK, Lowe RW, Wilhelm SI, Robertson GJ, Barrett RT, Anker-Nilssen T, Good TP (2012) Unintended consequences: how the recovery of sea eagle Haliaeetus spp. populations in the northern hemisphere is affecting seabirds. Mar Ornithol 40:39-52
Hyvärinen E, Juslén A, Kemppainen E, Uddström A, Liukko U (2019) The 2019 red list of Finnish species. Ministry of the Environment, Helsinki

Härmä P, Hatunen S, Törmä M, Järvenpää E, Kallio M, Teiniranta R, Kiiski T, Suikkanen J (2013) GIO Land Monitoring 2011-2013 in the framework of regulation (EU) No 911/2010. Final Report, Finland, p 47

Högmander J, Lokki H, Laaksonen T, Stjernberg T (2020) The Finnish White-tailed Eagle Haliaeetus albicilla population no longer endangered [in Finnish with English summary]. Linnutvuosikirja 2019:60-71

Jernsletten J, Klokov K (2002) Sustainable Reindeer Husbandry. University of Troms $\emptyset$, Troms $\varnothing$, Centre for Saami Studies

Johnsen T, Systad G, Jacobsen K, Nygård T, Bustnes J (2007) The occurrence of reindeer calves in the diet of nesting Golden Eagles in Finnmark, northern Norway. Ornis Fenn 84:112-118

Kohavi R (1995) A study of cross-validation and bootstrap for accuracy estimation and model selection. In: San Mateo CA (ed) Proceedings in International Joint Conference on Artificial Intelligence, Morgan Kaufmann, pp 1137-1143

Kohl KD, Coogan SCP, Raubenheimer D (2015) Do wild carnivores forage for prey or for nutrients? BioEssays 37:701-709. https:// doi.org/10.1002/bies.201400171

Krone O, Treu G (2018) Movement patterns of white-tailed sea eagles near wind turbines. J Wildl Manage 82:1367-1375. https://doi. org/10.1002/jwmg.21488

Kumpula J, Stark S, Holand $\emptyset$ (2011) Seasonal grazing effects by semidomesticated reindeer on subarctic mountain birch forests. Polar Biol 34:441-453. https://doi.org/10.1007/s00300-010-0899-4

LeDell E, Petersen M, van der Laan M (2014) cvAUC: Cross-validated Area Under the ROC Curve confidence intervals. R package version 1.1.0.

März R (1987) Gewöll- und Rupfungskunde. Akademie-Verlag, Berlin

Mersmann T, Buehler D, Fraser JD, Seegar J (1992) Assessing bias in studies of bald eagle food-habits. J Wildl Manage 56:73-78

Miller FL, Barry SJ (2009) Long-Term Control of Peary Caribou Numbers by Unpredictable, Exceptionally Severe Snow or Ice Conditions in a Non-Equilibrium Grazing System. Arctic 62:175-189. https://doi.org/10.14430/arctic130

Nadjafzadeh M, Hofer H, Krone O (2016) Sit-and-wait for large prey: foraging strategy and prey choice of White-tailed Eagles. J Ornithol 157:165-178. https://doi.org/10.1007/s10336-015-1264-8

Nadjafzadeh M, Hofer H, Krone O (2013) The link between feeding ecology and lead poisoning in white-tailed eagles. J Wildl Manage 77:48-57. https://doi.org/10.1002/jwmg.440

National Land Survey of Finland (2019) Municipal division. https:// www.maanmittauslaitos.fi/en. Accessed 11.9. 2019

Navarro-López J, Fargallo JA, Margalida A (2015) Trophic niche in a raptor species: The relationship between diet diversity, habitat diversity and territory quality. PLoS ONE. https://doi. org/10.1371/journal.pone.0128855

Newsome S, Tinker M, Gill V, Hoyt Z, Doroff A, Nichol L, Bodkin J (2015) The interaction of intraspecific competition and habitat on individual diet specialization: a near range-wide examination of sea otters. Oecologia 178:45-59. https://doi.org/10.1007/s0044 2-015-3223-8

Nyhus PJ (2016) Human-Wildlife Conflict and Coexistence. Annu Rev Environ Resour 41:143-171. https://doi.org/10.1146/annur ev-environ-110615-085634

O'Rourke E (2014) The reintroduction of the white-tailed sea eagle to Ireland: People and wildlife. Land Use Policy 38:129-137. https ://doi.org/10.1016/j.landusepol.2013.10.020

Oehme G (1975) Zur Ernährung des Seeadlers, Haliaeetus albicilla (L.), unter besonderer Berücksichtigung der Population in den drei Nordbezirken der DDR. Dissertation, Ernst-Moritz-ArndtUniversität, Greifswald 
Official Statistics of Finland (2019) Climatological statistics. Finnish Meteorological Institute. https://www.stat.fi/til/ilmatila/index _en.html. Accessed 5.6. 2019

Ollila T, Stjernberg T, Ojala S (2007) Merikotkan esiintymisen historia Lapissa [In Finnish; 'Historical records of the occurrence of White-Tailed Eagles in Lapland']. Sirri 32:56-58

Ontiveros D, Pleguezuelos JM, Caro J (2005) Prey density, prey detectability and food habits the case of Bonelli's eagle and the conservation measures. Biol Conserv 123:19-25. https://doi. org/10.1016/j.biocon.2004.10.004

Öst M, Lindén A, Karell P, Ramula S, Kilpi M (2018) To breed or not to breed: drivers of intermittent breeding in a seabird under increasing predation risk and male bias. Oecologia 188:129-138. https://doi.org/10.1007/s00442-018-4176-5

Picard RR, Cook RD (1984) Cross-Validation of Regression Models. J Am Stat Assoc 79:575-583. https://doi.org/10.1080/01621 459.1984.10478083

Ponnikas S, Kvist L, Ollila T, Stjernberg T, Orell M (2013) Genetic structure of an endangered raptor at individual and population levels. Conserv Genet 14:1135-1147. https://doi.org/10.1007/ s10592-013-0501-z

Poole A (2019) Ospreys: The Revival of a Global Raptor. Johns Hopkins University Press, Baltimore

Prugh LR, Stoner CJ, Epps CW, Bean WT, Ripple WJ, Laliberte AS, Brashares JS (2009) The Rise of the Mesopredator. Bioscience 59:779-791. https://doi.org/10.1525/bio.2009.59.9.9

R Core Team (2020) R: A language and environment for statistical computing. R Foundation for Statistical Computing

Radović A, Mikuska T (2009) Population size, distribution and habitat selection of the white-tailed eagle Haliaeetus albicilla in the alluvial wetlands of Croatia. Biologia 64:156-164. https://doi. org/10.2478/s11756-009-0011-0

Ratcliffe D (2003) The Peregrine saga. In: Thompson D (ed) Birds of prey in a changing environment. The Stationery Office, Edinburgh, pp 91-98

Ripple WJ, Estes JA, Beschta RL, Wilmers CC, Ritchie EG, Hebblewhite M, Berger J, Elmhagen B, Letnic M, Nelson MP, Schmitz OJ, Smith DW, Wallach AD, Wirsing AJ (2014) Status and ecological effects of the world's largest carnivores. Science 343:151162. https://doi.org/10.1126/science. 1241484

Scottish Natural Heritage (2017) White-tailed Eagle Action Plan 2017 $-2020$

Shin D, Yoo J, Jeong D, Shin D (2013) Spatial variation of Eurasian eagle-owl diets in wetland and non-wetland habitats in westcentral Korea. J Raptor Res 47:400-409. https://doi.org/10.3356/ JRR-13-00006.1

Sih A (2011) Foraging Theory. In: Scheiner SM, Willig MR (eds) The Theory of Ecology. University of Chicago Press, Chicago, pp 182-211

Silliman BR, Hughes BB, Gaskins LC, He Q, Tinker MT, Read A, Nifong J, Stepp R (2018) Are the ghosts of nature's past haunting ecology today? Curr Biol 28:532-537. https://doi.org/10.1016/j. cub.2018.04.002

Simms IC, Ormston CM, Somerwill KE, Cairns CL, Tobin FR, Judge. J, Tomlinson A (2010) A pilot study into sea eagle predation on lambs in the Gairloch area - Final Report. Scottish Natural Heritage Commissioned Report No. 370.,

Statistics Finland (2019) Municipal key figures. https://pxnet2.stat. fi/PXWeb/pxweb/en/Kuntien_avainluvut/?rxid=444223df-f91c4479-891f-5dcd50b983d2. Accessed 11.9. 2019

Stephens DW, Krebs JR (1986) Foraging theory. Princeton U.P, Princeton, N.J.
Stjernberg T, Koivusaari J, Högmander J, Ollila T, Ekblom H (2005) Population trends and breeding success of the white-tailed sea eagle Haliaeetus albicilla in Finland, 1970-2005. In: Status of raptor populations in eastern Fennoscandia, Proceedings of the Workshop, Kostomuksha, Karelia, Russia, pp 151-159

Stjernberg T, Nuuja I, Laaksonen T, Koivusaari J, Ollila T, Keränen S, Ekblom H, Lokki H, Saurola P (2016) Suomen merikotkat 20132015. Linnut-vuosikirja 2015:20-29 [in Finnish with English summary]

Sulkava S, Huhtala K, Rajala P, Tornberg R (1998) Changes in the diet of the Golden Eagle Aquila chrysaetos and small game populations in Finland in 1957-96. Ornis Fenn 76:1-16

Sulkava S, Tornberg R, Koivusaari J (1997) Diet of the White-tailed Eagle Haliaeetus albicilla in Finland. Ornis Fenn:65-78

Tapia L, Zuberogoitia I (2018) Breeding and nesting biology in raptors. In: Sarasola JH, Grande JM, Negro JJ (eds) Birds of prey: biology and conservation in the XXI century, Springer International Publishing, pp 63-94

Terraube J, Guixé D, Arroyo B (2014) Diet composition and foraging success in generalist predators: Are specialist individuals better foragers? Basic Appl Ecol 15:616-624. https://doi.org/10.1016/j. baae.2014.08.008

Tikkanen H, Balotari-Chiebao F, Laaksonen T, Pakanen V, Rytkönen S (2018) Habitat use of flying subadult White-tailed Eagles (Haliaeetus albicilla): implications for land use and wind power plant planning. Ornis Fenn 95:137

Tikkanen H, Rytkönen S, Karlin O, Ollila T, Pakanen V, Tuohimaa H, Orell M (2018) Modelling golden eagle habitat selection and flight activity in their home ranges for safer wind farm planning 71:120-131. https://doi.org/10.1016/j.eiar.2018.04.006

Treinys R, Dementavičius D, Rumbutis S, Švažas S, Butkauskas D, Sruoga A, Dagys M (2016) Settlement, habitat preference, reproduction, and genetic diversity in recovering the white-tailed eagle Haliaeetus albicilla population. J Ornithol 157:311-323. https:// doi.org/10.1007/s10336-015-1280-8

Tveraa T, Fauchald P, Henaug C, Yoccoz N (2003) An examination of a compensatory relationship between food limitation and predation in semi-domestic reindeer. Oecologia 137:370-376. https://doi. org/10.1007/s00442-003-1373-6

Väisänen RA, Hario M, Saurola P (2011) Population estimates of Finnish birds. In: Valkama J, Vepsäläinen V, Lehikoinen A (eds) The third Finnish breeding bird atlas. Finnish Museum of Natural History and Ministry of Environment. https://atlas3.lintuatlas.fi/engli sh, Helsinki. Accessed 26.2.2020

Valkama J, Korpimki E, Arroyo B, Beja P, Bretagnolle V, Bro E, Kenward R, Maosa S, Redpath SM, Thirgood S, Viuela J (2005) Birds of prey as limiting factors of gamebird populations in Europe: a review. Biol Rev 80:171-203. https://doi.org/10.1017/S1464 $79310400658 X$

Vasko V, Laaksonen T, Valkama J, Korpimäki E (2011) Breeding dispersal of Eurasian kestrels Falco tinnunculus under temporally fluctuating food abundance. J Avian Biol 42:552-563. https://doi. org/10.1111/j.1600-048X.2011.05351.x

Zuur A, Ieno E, Elphick CS (2010) A protocol for data exploration to avoid common statistical problems. Methods Ecol Evol 1:3-14. https://doi.org/10.1111/j.2041-210X.2009.00001.x

Publisher's Note Springer Nature remains neutral with regard to jurisdictional claims in published maps and institutional affiliations. 